\title{
Effect of including n-3/n-6 fatty acid feed sources in diet on fertility and hatchability of broiler breeders and post-hatch performance and carcass parameters of progeny
}

\author{
Seyyed Naeim Saber ${ }^{1, *}$ and Hasan Rustu Kutlu
}

\author{
* Corresponding Author: Seyyed Naeim Saber \\ Tel: +90-5313296266, Fax: +90-322-338-68-22, \\ E-mail: Naeim_saber@yahoo.com \\ 'Animal Science Department, Faculty of Agriculture, \\ Cukurova University, Adana, 1330, Turkey \\ ORCID \\ Seyyed Naeim Saber \\ https://orcid.org/0000-0002-9635-7105 \\ Hasan Rustu Kutlu \\ https://orcid.org/0000-0002-3891-1534
}

Submitted Jan 16, 2019; Revised Feb 23, 2019; Accepted Mar 28, 2019
Objective: The present trial was conducted to determine the influence of different dietary fatty acid (omega- 3 and omega-6) sources on reproductive performance of female broiler breeders and growth performance and carcass traits of their progeny.

Methods: Two hundred and twenty, 25 weeks old Ross-308 male (20) and female (200) broiler breeders were used in the experiment for the period of 6 weeks. All birds were randomly divided into four dietary treatments (containing $2 \%$ soybean oil, $2 \%$ sunflower oil, $2 \%$ flaxseed oil, and 2\% fish oil) each with five replicates of one male and ten females. Throughout this experiment hatching performance of broiler breeders, progeny growth performance and carcass parameters were recorded.

Results: The results showed that the inclusion of different fatty acid sources in female broiler breeders diet had no significant effects ( $p>0.05$ ) on number of fertile eggs, post-hatch mortality, and fertility rate. The soybean oil supplemented group had significantly $(\mathrm{p}<0.05)$ higher late embryonic mortality compared to other three treatments.

Conclusion: It was concluded that inclusion of $2 \%$ of different sources of omega- 3 and omega- 6 fatty acids (especially $2 \%$ flax seed oil) in broiler breeders' diet can reduce late embryonic mortality. The other reproductive characteristics of parents and growth and carcass characteristics of progeny remained unaltered by dietary sources of omega- 3 and omega- 6 fatty acids.

Keywords: Breeder; n-3/n-6 Fatty Acid; Hatchability; Progeny

\section{INTRODUCTION}

It is well recognized that hatchability and female reproductive performance are the most important factors in poultry production. In poultry industry, some parameters such as hatchability and abdominal fat deposition [1], fatty acid profile of egg yolk [2,3], and lipid metabolism in chicks [4] can be influenced by the ratio of dietary omega- 3 to omega- 6 fatty acids, as the commercial diets used in breeders are formulated in favor of omega- 6 . However, it has been reported that the absolute amount of n-3 and n- 6 fatty acids in broiler breeder diet may be more important than n-6/n-3 fatty acid ratios and should be considered in the reproductive and performance traits of breeders. Therefore, it is necessary to supply higher levels of n-3 and n-6 fatty acid with respect to n-6/n-3 fatty acid ratios [5]. It is hypothesized that inclusion of omega- 3 and omega- 6 in broiler breeders' diet could potentially improve incubation parameters and progeny performance by improving egg yolks' fatty acid profile and transitioning these fatty acids from egg to embryonic tissues. It has long been known that egg yolk is the primary energy source for embryos during their development, whose nutrient profile changes with the maternal diet $[6,7]$ and thereby differences in yolk would create 
differences in the nutritional status of progeny [8]. Some studies reported that normal embryonic growth and development depend on a complete supply of nutrients within the egg and it can influence hatchability, fertility, progeny growth, immunity, and carcass characteristics [9-11]. Various research findings have indicated that one of those nutrients is omega-3 fatty acid but the present literature presents conflicting results; it has been reported that diets enriched with omega-3 polyunsaturated fatty acid have an improving effect on immunity [12] but another study reported no beneficial effects of omega-3 fatty acid [13] or a detrimental effect on chickens' immunity [14]. It should also be noted that yolk omega-3 fatty acid has an unique role in eicosanoid metabolism and modulation of progeny as omega-3 fatty acid is taken up from yolk sac lipids and incorporated into cell membrane phospholipids of the developing embryo during avian embryo genesis and post hatch growth $[3,4]$. It has been reported that during embryo development fatty acid from the maternal diet incorporated in the yolk is transferred into liver of offspring through the yolk residual by the time of hatching [3]. Moreover, in our previous experiment, we observed that dietary inclusion of $2 \%$ flaxseed oil as a source of omega- 3 had a potential to improve laying performance, egg quality parameters, and egg yolk fatty acid composition in broiler breeders [2]. The present study was, therefore, aimed to investigate the effects of dietary inclusion of omega-3 fatty acids from flaxseed oil and/or fish oil and omega- 6 fatty acids from soya oil in broiler breeders' diet on hatchability, fertility, and post-hatch growth performance and carcass parameters of progeny.

\section{MATERIALS AND METHODS}

\section{General experimental procedure and trial groups}

The present study was carried out in the Broiler Unit of Experimental Farm of the Department of Animal Science, Faculty of Agriculture, University of Cukurova-Turkey. All the protocols used in this experiment were approved by the Animal Experiments Local Ethics Committee of Cukurova University, Adana-Turkey.

Two hundred and twenty, 25 weeks old Ross-308 (200 female and 20 male) broilers were used in this experiment. During pre-feeding period (25 and 26th weeks), all broiler breeders were fed with standard breeder diet based on corn and soybean. After 2 weeks of pre-feeding period all female birds were divided according to body weight and egg production in a completely randomized design into four experimental diets (Table 1) containing $2 \%$ soybean oil or $2 \%$ sunflower oil or $2 \%$ flax seed oil or $2 \%$ fish oil groups with five replicate pens for each treatment and therefore total 20 replicates, each containing ten females and one male. All male broiler breeders

Table 1. Composition and calculated analysis of the basal diet given female breeders

\begin{tabular}{|c|c|c|c|c|c|c|}
\hline \multirow{2}{*}{ Ingredients (\%) } & \multicolumn{4}{|c|}{ Dietary treatments } & \multirow{2}{*}{ Nutrient composition (\%) } & \\
\hline & so & SA & $\mathrm{FL}$ & $\mathrm{FI}$ & & \\
\hline Yellow corn & 54.49 & 54.49 & 54.49 & 54.49 & Dry matter & 88.52 \\
\hline Soybean meal & 10.00 & 10.00 & 10.00 & 10.00 & Crude protein $(\mathrm{N} \times 6.25)$ & 19.00 \\
\hline Fullfat soybean & 9.64 & 9.64 & 9.64 & 9.64 & Crude fiber & 3.58 \\
\hline Limestone (GRN) & 7.71 & 7.71 & 7.71 & 7.71 & Crude fat & 3.71 \\
\hline Sunflower meal-36 & 7.46 & 7.46 & 7.46 & 7.46 & Crude ash & 13.35 \\
\hline Corn gluten meal-60 & 3.86 & 3.86 & 3.86 & 3.86 & Starch & 34.99 \\
\hline Meat-Bone35 & 2.48 & 2.48 & 2.48 & 2.48 & Metabolizable energy (poultry, kcal/kg) & 2,680 \\
\hline DCP-18 & 1.57 & 1.57 & 1.57 & 1.57 & $\mathrm{Ca}$ & 3.65 \\
\hline Soybean oil & 2 & - & - & - & Tot. $P$ & 0.78 \\
\hline Sunflower oil & - & 2 & - & - & Ava-P & 0.50 \\
\hline Flax seed oil & - & - & 2 & - & $\mathrm{Na}$ & 0.16 \\
\hline Fish oil & - & - & - & 2 & Lysine & 0.87 \\
\hline Salt & 0.24 & 0.24 & 0.24 & 0.24 & Methionine & 0.37 \\
\hline Vitamin premix ${ }^{1)}$ & 0.20 & 0.20 & 0.20 & 0.20 & Methionine+cystine & 0.70 \\
\hline Mineral premix ${ }^{2)}$ & 0.10 & 0.10 & 0.10 & 0.10 & Tryptophan & 0.20 \\
\hline Sodium bicarbonate & 0.10 & 0.10 & 0.10 & 0.10 & Threonine & 0.70 \\
\hline L-lysine & 0.06 & 0.06 & 0.06 & 0.06 & Arginine & 1.20 \\
\hline Choline-60 & 0.05 & 0.05 & 0.05 & 0.05 & Isoleucine & 0.76 \\
\hline DL-methionine & 0.04 & 0.04 & 0.04 & 0.04 & Valine & 0.89 \\
\hline Total & 100 & 100 & 100 & 100 & & \\
\hline
\end{tabular}

SO, $2 \%$ soybean oil; SA, $2 \%$ sunflower oil; FL, $2 \%$ flaxseed oil; Fl, $2 \%$ fish oil.

1) Vitamin premix (per $2 \mathrm{~kg}$ of diet): vitamin $\mathrm{A}, 16,000 \mathrm{IU}$; vitamin $\mathrm{D}_{3}, 3,000 \mathrm{IU}$; vitamin $\mathrm{E}, 40 \mathrm{IU}$; vitamin $\mathrm{K}_{3}, 2.5 \mathrm{mg}$; vitamin $\mathrm{B}_{1}, 2.5 \mathrm{mg}$; vitamin $\mathrm{B}_{2}, 10 \mathrm{mg}$; nicotinamide, 50 mg; calcium D-pantothenate, 15 mg; vitamin $B_{6}, 6.25$ mg; vitamin $B_{12}, 0.035$ mg; folic acid, 15 mg; D-biotin, 0.045 mg; choline chloride, $150 \mathrm{mg}$.

${ }^{2)}$ Mineral premix (mg/kg of diet): $\mathrm{Mn}, 80 ; \mathrm{Fe}, 80 ; \mathrm{Zn}, 60 ; \mathrm{Cu}, 8 ; \mathrm{Co}, 0.2 ; \mathrm{I}, 0.5 ; \mathrm{Se}, 0.15$. 
were fed with standard breeder diet based on corn and soybean (pre-feeding period diet). Fatty acids composition of oil sources used in this experiment is shown in Table 2. The trial lasted for 6 weeks (27 to 32th weeks of age). Each pen (sizing $2 \times 1.5$ meters) of the breeder unit had five nests bedded with wood shaving, sized $25 \times 43 \times 35 \mathrm{~cm}$ each, a female tubular feeder and one individual male feeder and nipple drinkers. The birds were placed on wood shaving litter 7 to $8 \mathrm{~cm}$ height. The lighting (16:8 light:dark photoperiod) and feed (female: $163 \mathrm{~g} / \mathrm{d}$, male: $130 \mathrm{~g} / \mathrm{d}$ ) were provided according to the recommendation of Ross Breeding Company [15] with ad libitum access to drinking water. The environmental temperature $\left(18^{\circ} \mathrm{C}\right.$ to $\left.22^{\circ} \mathrm{C}\right)$ and humidity $(55 \%$ to $60 \%$ relative humidity $[\mathrm{RH}]$ ) were maintained within the animal comfort zone using foggers and tunnel ventilation. During the experiment, males' performances were observed and the males with low mating performance were replaced with spare males.

\section{Fertility and hatching performance}

At the 30th week of age, eggs were checked and collected for fertility testing (with bright light) and to understand male broiler breeders reproductive performance before incubation. The hatching capacity of the eggs, obtained from the broiler breeders, receiving different sources of omega- 3 and omega- 6 fatty acids was examined in the 21 st day of incubation. For this purpose, at 31st and 32nd weeks of age, the eggs with double yolk, dirty eggs, thin shell eggs, broken eggs, and cracked eggs were removed and the remaining ones stored in a cool room $\left(12^{\circ} \mathrm{C}\right.$ with $\left.70 \mathrm{RH}\right)$ until we obtained 700 eggs ( 35 for each replicate). The eggs were incubated in a single stage incubator and temperature was controlled according to McQuoid [16]. At the end of 21st day of incubation, all hatched chicks were carefully taken from the pouches and weighted by an electronic scale with a sensitivity of $0.01 \mathrm{~g}$. After weighting, the chicks were sexed by wing feathers according to Ross (Aviagen) [17] recommendation. The eggs that failed to hatch were broken to determine the cause and to classify as infertile or dead embryos to calculate hatchability of total as well as fertile eggs. A visual estimation of the age at death was carefully performed and embryo mortality was separated as early, mid and late dead in shell (1 to 7 days; 8 to 14 days; 15 to 21 days). The percentage of hatching chicks considered unsuitable for placement as well as pips was calculated. The difference between total eggs set and infertile eggs allowed the calculation of the present hatchability of fertile eggs. So, fertility rate (\%), total hatchability (\%), and hatchability of fertile eggs (\%) were calculated [18] as given below;

Table 2. Fatty acids composition of oil sources used in broiler breeder diets (\%)

\begin{tabular}{|c|c|c|c|c|c|}
\hline \multirow{2}{*}{ Numeric name } & \multirow{2}{*}{ Common name } & \multicolumn{4}{|c|}{ Oil sources } \\
\hline & & so & SA & $\mathrm{FL}$ & $\mathrm{FI}$ \\
\hline $\mathrm{C} 12: 0$ & Lauric asit & 0.06 & 0.05 & 0.03 & 0.03 \\
\hline C14:1 & Miristoleic acid & - & - & - & 0.14 \\
\hline $\mathrm{C} 16: 0$ & Palmitic acid & 10.05 & 5.79 & 5.94 & 12.50 \\
\hline C16:1 & Palmitoleic acid & 0.34 & 0.24 & 0.24 & 4.28 \\
\hline $\mathrm{C} 17: 1$ & cis-17-heptadecenoic acid & 0.04 & - & - & 0.16 \\
\hline C18:0 & Stearic acid & 4.56 & 3.88 & 4.36 & 3.80 \\
\hline C18:1 n9 & oleic acid & 23.54 & 34.98 & 24.53 & 28.57 \\
\hline C18:2 n6 & Linoleic acid & 52.80 & 53.47 & 14.68 & 11.21 \\
\hline C18:3 n3 & Linolenic acid & 7.68 & 0.22 & 49.87 & 4.14 \\
\hline C20:0 & Arachidic acid & - & - & - & 0.79 \\
\hline C20:4 n6 & Arachidonic acid & - & - & - & 4.95 \\
\hline C20:5 n3 (EPA) & cis-5,8,11,14,17-eicosapentaenoic acid & - & - & - & 3.24 \\
\hline $\mathrm{C} 22: 2$ & cis-13,16-Docosadienoic acid & - & - & - & 0.18 \\
\hline C22:6 n3 (DHA) & cis-4,7,10,13,16,19-Docosahexaenoic acid & - & - & - & 8.53 \\
\hline Total of omega-3 fatty acids & & 7.68 & 0.22 & 49.87 & 15.91 \\
\hline Total of omega- 6 fatty acids & & 52.80 & 53.47 & 14.68 & 16.88 \\
\hline Total of saturated fatty acids & & 14.72 & 9.72 & 10.32 & 21.19 \\
\hline Total of mono unsaturated fatty acids & & 23.92 & 35.22 & 24.77 & 33.33 \\
\hline Total of polyunsaturated fatty acids & & 60.48 & 53.69 & 64.54 & 32.98 \\
\hline
\end{tabular}

SO, soybean oil; SA, sunflower oil; FL, flax oil; Fl, fish oil. 
Fertility rate (\%)

$=($ no of fertile eggs $/$ no of eggs placed in hatchery $) \times 100$

Total hatchability (\%)

$=($ no of chicks hatched/no of eggs placed in hatchery $) \times 100$

Hatchability of fertile eggs (\%)

$=$ (no of chicks hatched

/no of fertile eggs placed in hatchery) $\times 100$

\section{Growth performance of progeny}

At the end of the incubation, all chicks obtained from the eggs were carefully taken and divided into 20 pens by the maternal group/subgroup number to follow on the same axis as the maternal to its chicks. Each treatment group had 5 pens sized $2 \times 3 \mathrm{~m}$ that were equipped with a tube feeder and an automatic water-bowl on litter; wood shaving litter 7 to $8 \mathrm{~cm}$ height. During the experiment, all chicks were fed with starter ( 0 to 10 days of age), grower (11 to 21 days of age), finisher (22 to 29 days of age), and withdrawal (30 to 35 days of age) diets formulated as per Ross recommendations [17]. Chicks were fed for 35 days ad libitum under a 23:1 light:dark photoperiod. Ingredient and nutritional compositions of the diet are given in Table 3.

The production parameters like live weight, feed intake and feed efficiency were recorded weekly during the experiment. At 35 th day of age, all the birds were subjected to slaughter studies.

Table 3. Ingredient and nutrient compositions of broiler diets

\begin{tabular}{|c|c|c|c|c|}
\hline Ingredients (\%) & $\begin{array}{c}\text { Starter } \\
\text { (0 to } 10 \text { days) }\end{array}$ & $\begin{array}{c}\text { Grower } \\
\text { (11 to } 21 \text { days) }\end{array}$ & $\begin{array}{c}\text { Finisher } \\
\text { (22 to } 29 \text { days) }\end{array}$ & $\begin{array}{c}\text { Withdrawal } \\
\text { (30 to } 35 \text { days) }\end{array}$ \\
\hline Yellow corn & 43.17 & 46.63 & 50.70 & 50.76 \\
\hline Soybean meal (47.5\% CP) & 15.64 & 7.71 & - & - \\
\hline Full fat soya & 14.17 & 16.68 & 26.21 & 26.21 \\
\hline Wheat short (15\% CP) & 13.03 & 13.00 & 11.17 & 11.17 \\
\hline Maize gluten meal (60\% CP) & 5.00 & 3.00 & - & - \\
\hline Poultry offal meal (52\% CP) & - & 4.00 & 4.00 & 4.00 \\
\hline Meat-Bone meal (33\% CP) & 4.00 & 5.27 & 4.49 & 4.49 \\
\hline Soya oil & 2.00 & 2.00 & 2.00 & 2.00 \\
\hline DCP $(18 \% P)$ & 0.60 & - & - & - \\
\hline Sodium bicarbonate & 0.11 & 0.08 & - & - \\
\hline Common salt & 0.17 & 0.14 & 0.21 & 0.21 \\
\hline Bio-lysine (60\%) & 0.77 & 0.60 & 0.36 & 0.36 \\
\hline Limestone & 0.61 & 0.28 & 0.26 & 0.26 \\
\hline DL-methionine & 0.36 & 0.25 & 0.24 & 0.24 \\
\hline Anticoccidial & 0.06 & 0.06 & 0.06 & - \\
\hline Vitamin premix ${ }^{1)}$ & 0.20 & 0.20 & 0.20 & 0.20 \\
\hline Mineral premix ${ }^{2)}$ & 0.10 & 0.10 & 0.10 & 0.10 \\
\hline Total & 100.00 & 100.00 & 100.00 & 100.00 \\
\hline \multicolumn{5}{|l|}{ Nutrient composition (\%) } \\
\hline Dry matter & 88.00 & 88.00 & 88.00 & 88.00 \\
\hline Crude protein & 24.00 & 22.00 & 21.00 & 20.00 \\
\hline Ether extract & 7.00 & 8.66 & 10.13 & 10.13 \\
\hline Crude fibre & 3.20 & 3.17 & 3.37 & 3.37 \\
\hline Crude ash & 6.03 & 5.80 & 5.48 & 5.48 \\
\hline Lysine & 1.43 & 1.26 & 1.09 & 1.09 \\
\hline Methionine & 0.70 & 0.56 & 0.50 & 0.50 \\
\hline Methionine+cystine & 1.07 & 0.84 & 0.86 & 0.86 \\
\hline Calcium & 1.00 & 1.00 & 0.90 & 0.90 \\
\hline Available phosphor & 0.45 & 0.45 & 0.40 & 0.40 \\
\hline Sodium & 0.16 & 0.16 & 0.16 & 0.16 \\
\hline Metabolizable energy (kcal/kg) & 3,050 & 3,150 & 3,250 & 3,250 \\
\hline
\end{tabular}

CP, crude protein; DCP, dicalcium phosphate.

1) Each $2 \mathrm{~kg}$ of vitamin premix contains: $15,500,000 \mathrm{IU}$ vitamin $\mathrm{A} ; 5,000,000 \mathrm{IU}$ vitamin $\mathrm{D}_{3} ; 100,000 \mathrm{mg}$ vitamin $\mathrm{E} ; 3,000 \mathrm{mg}$ vitamin $\mathrm{K}_{3} ; 3,000 \mathrm{mg}$ vitamin $\mathrm{B}_{1} ; 8,000 \mathrm{mg}$ vitamin $B_{2} ; 60,000 \mathrm{mg}$ niacin; $15,000 \mathrm{mg}$ Ca-D-Pantotenate; 5,000 mg vitamin $\mathrm{B}_{6} ; 20 \mathrm{mg}$ vitamin $\mathrm{B}_{12} ; 2,000 \mathrm{mg}$ folic acid; $200 \mathrm{mg}$ D-biotin; and 100,000 mg vitamin C.

2) Each $\mathrm{kg}$ of trace mineral premix contains: $80,000 \mathrm{mg}$ manganese; $60,000 \mathrm{mg}$ iron; $60,000 \mathrm{mg}$ zinc; $5,000 \mathrm{mg}$ copper; $200 \mathrm{mg}$ cobalt; 1,000 mg iodine; $200 \mathrm{mg}$ selenium (sodium selenite); 500,000 choline chloride. 


\section{Carcass parameters of progeny}

At the end of the experiment ( 35 days of age), all chicks were weighted and 6 birds ( 3 male +3 female) from each subgroup were selected and slaughtered according to the average body weight of groups in order to determine the hot carcass weight, abdominal fat, and carcass yield.

\section{Statistical analysis}

The data obtained in the study were analysed using general linear model procedure of the Statistical Analysis System [19] to obtain the effect of oil source. Duncan's New Multiple Range Test in SAS was used to identify significant differences among treatments means [19]. Results obtained in this study were presented as means per bird with standard errors of the difference between means (SED; $\sqrt{\frac{S^{2}}{\mathrm{n}}}$ ) with p values, except for feed intake of breeders as feeds were given to the them in equal amounts according to the recommendation of the Breeding Company [17].

\section{RESULTS}

\section{Fertility and hatching performance}

The effects of dietary inclusion of omega- 3 and omega- 6 fatty acids sources on hatchability and fertility parameters in broiler breeders are given in Table 4 . The dietary omega- 3 and omega- 6 fatty acids did not have a significant $(\mathrm{p}<0.05)$ effect on number of fertile eggs, embryonic mortality in early stage, embryonic mortality in mid stage, post-hatch mortality and fertility rate. However, results of the present experiment showed that the inclusion of different sources of omega- 3 and omega- 6 fatty acids in breeder diets had a significant $(\mathrm{p}<0.05)$ effect on late stage embryo mortality, number of chicks hatched alive, chicks' weight at hatching, hatchability of fertile eggs and total hatchability.

\section{Growth performance of progeny}

The effects of different dietary fatty acid sources in maternal diet on progeny performance were obtained as shown in Table 5. On perusal of the results of weekly feed intake of broiler chickens, it was seen that the inclusion of different dietary sources of omega- 3 and omega- 6 fatty acids in their parents' diets had no significant effect on production performance of broiler progeny.

\section{Carcass parameters of progeny}

The effects of the inclusion of different fatty acid sources in maternal diet on carcass parameters of progeny were analyzed as shown in Table 6. There were no significant effects on body weight parameter between experimental groups ( $\mathrm{p}>$ 0.05 ). Inclusion of $2 \%$ different fatty acids in broiler breeders' diet did not affect any of the carcass traits (hot carcass weight, abdominal fat, and carcass yield) studied in this experiment.

\section{DISCUSSION}

The results obtained in the trial suggest that inclusion of omega-3 and omega- 6 fatty acid sources in broiler breeders' diets had significant effect on incubation parameters. The results of this experiment are in agreement with the findings of AlDaraji et al [20] who found that adding of 3\% corn, fish, flax, and sunflower oil in quails diet had a significant effect on fer-

Table 4. The effect of dietary fatty acid ( $n-3$ and $n-6)$ sources on hatching performance in broiler breeders

\begin{tabular}{|c|c|c|c|c|c|c|}
\hline \multirow{2}{*}{ Parameters } & \multicolumn{4}{|c|}{ Dietary fat sources } & \multirow{2}{*}{ SED } & \multirow{2}{*}{$p$-value } \\
\hline & SO & SA & $\mathrm{FL}$ & $\mathrm{FI}$ & & \\
\hline Number of eggs placed hatchery (No/replication) & 35 & 35 & 35 & 35 & - & - \\
\hline Number of fertile eggs (number/replication) & 34.40 & 33.60 & 34.60 & 34.40 & 0.18 & 0.263 \\
\hline Embryonic mortality in early stage & 1.00 & 1.80 & 0.80 & 1.80 & 0.23 & 0.340 \\
\hline Embryonic mortality in mid stage & 0.00 & 0.80 & 0.40 & 0.40 & 0.15 & 0.346 \\
\hline Embryonic mortality in late stage & $4.40^{\mathrm{a}}$ & $1.60^{b}$ & $0.40^{b}$ & $1.60^{b}$ & 0.32 & 0.003 \\
\hline Number of chicks hatched alive & 28.00 & 29.20 & 32.00 & 30.20 & 0.56 & 0.121 \\
\hline Male (number) & 15.20 & 12.40 & 14.00 & 15.00 & $\chi^{2 * *}=5.25$ & 0.154 \\
\hline Female (number) & 12.80 & 16.80 & 18.00 & 15.20 & & \\
\hline Chicks' weight at hatching (g/chick) & 48.85 & 50.81 & 53.60 & 53.01 & 0.66 & 0.082 \\
\hline Post-hatch mortality (number) & 0.80 & 0.20 & 0.20 & 0.20 & 0.10 & 0.121 \\
\hline Crippled chicks (number) & 0.20 & 0.00 & 0.80 & 0.20 & 0.11 & 0.130 \\
\hline Fertility rate $(\%)$ & 98.29 & 96.00 & 98.86 & 98.28 & 0.52 & 0.263 \\
\hline Hatchability of fertile eggs (\%) & 84.30 & 87.62 & 95.36 & 88.86 & 1.44 & 0.090 \\
\hline Total hatchability (\%) & $82.86^{b}$ & $84.00^{b}$ & $94.29^{\mathrm{a}}$ & $87.43^{\mathrm{ab}}$ & 1.50 & 0.065 \\
\hline
\end{tabular}

SO, $2 \%$ soybean oil; SA, $2 \%$ sunflower oil; FL, $2 \%$ flaxseed oil; FI, $2 \%$ fish oil; SED, standard errors of the difference.

$a, b$ Means within a row lacking a common superscript differ significantly $(p<0.05)$.

** Number of chicks hatched alive analyzed with $\chi^{2}$ test. 
Table 5. The effect of different dietary omega-3 and omega-6 fatty acid sources of female breeders on growth performance and slaughter weight of progeny

\begin{tabular}{|c|c|c|c|c|c|c|c|}
\hline \multirow{2}{*}{ Day } & \multirow{2}{*}{ Parameters } & \multicolumn{4}{|c|}{ Maternal diets oil sources } & \multirow{2}{*}{ SED } & \multirow{2}{*}{ p-value } \\
\hline & & SO & SA & $\mathrm{FL}$ & $\mathrm{FI}$ & & \\
\hline \multirow[t]{3}{*}{7} & Feed intake (g/chicks) & 215.8 & 196.2 & 190.2 & 206.2 & 3.86 & 0.137 \\
\hline & Body weight (g/chicks) & 144.5 & 150.03 & 149.1 & 148.4 & 2.40 & 0.517 \\
\hline & Feed conversion rate (g feed intake/g BWG) & 1.50 & 1.32 & 1.28 & 1.39 & 0.02 & 0.078 \\
\hline \multirow[t]{3}{*}{14} & Feed intake (g/chicks) & 718.3 & 685.8 & 645.2 & 693.8 & 10.28 & 0.129 \\
\hline & Body weight (g/chicks) & 455.7 & 457.2 & 454.6 & 464.9 & 5.96 & 0.853 \\
\hline & Feed conversion rate(g feed intake/g BWG) & 1.58 & 1.51 & 1.42 & 1.49 & 0.02 & 0.171 \\
\hline \multirow[t]{3}{*}{21} & Feed intake (g/chicks) & 1,369 & 1,334 & 1,332 & 1,368 & 18.14 & 0.808 \\
\hline & Body weight (g/chicks) & 867.9 & 866.0 & 880.2 & 888.6 & 9.70 & 0.736 \\
\hline & Feed conversion rate (g feed intake/g BWG) & 1.58 & 1.54 & 1.51 & 1.54 & 0.02 & 0.729 \\
\hline \multirow[t]{3}{*}{28} & Feed intake (g/chicks) & 2,262 & 2,347 & 2,321 & 2,362 & 26.67 & 0.584 \\
\hline & Body weight (g/chicks) & 1,579 & 1,570 & 1,571 & 1,563 & 13.38 & 0.992 \\
\hline & Feed conversion rate (g feed intake/g BWG) & 1.43 & 1.50 & 1.48 & 1.51 & 0.01 & 0.393 \\
\hline \multirow[t]{3}{*}{35} & Feed intake (g/chicks) & 3,486 & 3,586 & 3,630 & 3,668 & 42.43 & 0.485 \\
\hline & Body weight (g/chicks) & 2,397 & 2,415 & 2,375 & 2,416 & 29.05 & 0.955 \\
\hline & Feed conversion rate (g feed intake/g BWG) & 1.46 & 1.49 & 1.53 & 1.52 & 0.01 & 0.505 \\
\hline \multirow[t]{2}{*}{ Livability (\%) } & Male & 88.55 & 91.23 & 88.99 & 91.00 & 1.89 & 0.940 \\
\hline & Female & 89.69 & 85.54 & 91.29 & 89.37 & 3.09 & 0.924 \\
\hline \multirow[t]{4}{*}{ At slaughter } & Live weight (g/bird) & & & & & & \\
\hline & Male & 2,644 & 2,622 & 2,614 & 2,621 & 27.56 & 0.986 \\
\hline & Female & 2,355 & 2,330 & 2,279 & 2,334 & 19.91 & 0.634 \\
\hline & Average & 2,515 & 2,466 & 2,429 & 2,470 & 23.58 & 0.703 \\
\hline
\end{tabular}

SO, 2\% soybean oil; SA, 2\% sunflower oil; FL, 2\% flaxseed oil; FI, 2\% fish oil; SED, standard errors of the difference; BWG, body weight gain.

tility, hatchability of total eggs, hatchability of fertility eggs, and embryonic mortality. Also Bozkurt et al [10] suggested that adding of herbal essential mixture oil in broiler breeders' diet had a significant effect on fertility, hatchability of total eggs, chick weight, and total chicks ( $\mathrm{p}<0.05)$. But our experiment results are in disagreement with the finding of Koppenol et al [4] , who reported that supplementation of broiler breed- ers' diet with DHA and EPA does not have significant effect on incubation parameters ( $\mathrm{p}>0.05)$. Also Pirsarayi et al [21] suggested that adding of different levels of tallow in broiler breeders' diet did not have a significant effect on livability, fertility, and hatchability. It was also reported that laying quails' diet containing flax seed oil could improve the productive traits and this might be attributed to hormone metabolism

Table 6. The effect of different dietary omega-3 and omega-6 fatty acid sources of parents on carcass parameters of progeny

\begin{tabular}{|c|c|c|c|c|c|c|c|}
\hline \multirow{2}{*}{ Parameters } & \multirow{2}{*}{ Gender } & \multicolumn{4}{|c|}{ Maternal diets oil sources } & \multirow{2}{*}{ SED } & \multirow{2}{*}{$\mathrm{p}$-value } \\
\hline & & SO & SA & $\mathrm{FL}$ & $\mathrm{FI}$ & & \\
\hline \multirow[t]{3}{*}{ Body weight (g/chicks) } & Male & 2,745 & 2,756 & 2,740 & 2,820 & 16.79 & 0.304 \\
\hline & Female & 2,351 & 2,413 & 2,362 & 2,387 & 10.22 & 0.147 \\
\hline & Average & 2,548 & 2,584 & 2,551 & 2,607 & 17.01 & 0.559 \\
\hline \multirow[t]{3}{*}{ Hot carcass weight (g/chicks) } & Male & 1,917 & 1,923 & 1,930 & 1,974 & 12.69 & 0.388 \\
\hline & Female & 1,645 & 1,695 & 1,652 & 1,679 & 7.82 & 0.093 \\
\hline & Average & 1,781 & 1,809 & 1,791 & 1,795 & 15.23 & 0.931 \\
\hline \multirow[t]{3}{*}{ Abdominal fat (g/chicks) } & Male & 21.09 & 22.88 & 24.46 & 25.11 & 0.76 & 0.255 \\
\hline & Female & 18.23 & 15.36 & 15.49 & 15.28 & 0.71 & 0.112 \\
\hline & Average & 19.66 & 19.12 & 19.98 & 20.05 & 0.53 & 0.926 \\
\hline \multirow[t]{3}{*}{ Abdominal fat (\%) } & Male & 1.09 & 1.18 & 1.25 & 1.25 & 0.03 & 0.351 \\
\hline & Female & 1.10 & 0.91 & 0.94 & 0.90 & 0.02 & 0.067 \\
\hline & Average & 1.10 & 1.04 & 1.10 & 3.61 & 0.62 & 0.383 \\
\hline \multirow[t]{3}{*}{ Carcass yield (\%) } & Male & 69.78 & 69.81 & 70.43 & 69.98 & 0.15 & 0.421 \\
\hline & Female & 69.97 & 70.22 & 69.96 & 70.30 & 0.16 & 0.840 \\
\hline & Average & 69.88 & 70.02 & 70.20 & 68.72 & 0.36 & 0.489 \\
\hline
\end{tabular}

SO, $2 \%$ soybean oil; SA, $2 \%$ sunflower oil; FL, $2 \%$ flaxseed oil; Fl, $2 \%$ fish oil; SED, standard errors of the difference. 
regulation, mainly estrogen [22]. In another study, it was reported that yolk fat is a primary and important source of energy and essential nutrient for embryonic development [7, 23]. It has been hypothesized that some fatty acids such as eicosapentaenoic acid and docosahexenoic acid available in yolk are essential for embryonic development and they can improve incubation parameters such as chicks' quality and prevent embryo mortality in different stages of embryo development. In the present study, it was shown that the inclusion of omega fatty acids can prevent embryonic mortality in late stage.

Inclusion of $2 \%$ different omega- 3 and omega- 6 fatty acids in broiler breeders' diet had a significant effect on progeny feed intake and feed conversion ratio at the 7th and 14th day of age but this difference disappeared after 15th day of age. When the body weight parameter is investigated, it can be seen that there is not a significant difference between progeny during the experiment. Speake et al [24] reported that liver is a main organ for lipid metabolism and fatty acids from the yolk are transferred via the portal system to the developing liver of embryo. On the other hand, Wilson [25] explained that the eggs with large size have larger chicks and this advantage continues into market age. In this experiment larger eggs obtained from broiler breeders which received diets containing sunflower oil, fish oil, and fish oil dietary oils which led to the production of heavy chicks. Therefore, the existing difference $(p<0.05)$ in feed conversion ratio at the 7 th and 14th days of age is related to the chicks' weight at hatching time. So, it can be said that inclusion of different sources of oil maternal diets does not affect post-hatch feed intake and body weight. The results obtained from this study were in line with Pappas et al [26,7] studies. They reported that supplementation of broiler breeders' with eicosapentaenoic acid caused a lower daily weight gain of the progeny during starter period and this supplementation did not have a significant effect on feed intake in progeny.

In this study, there were not any significant effect on the average of hot carcass weight, abdominal fat, and carcass yield. This experiment results are disagreement with the finding of Kidd et al [27]. They stated that manipulation of breeders' diet with L-carnitine $(25 \mathrm{mg} / \mathrm{kg})$ had a significant effect on carcass fat and breast meat in male and female progeny.

\section{CONCLUSION}

The results obtained from this study showed that inclusion of $2 \%$ of different sources of omega- 3 and omega- 6 fatty acids (especially $2 \%$ flax seed oil) in broiler breeders' diet can influence late embryonic mortality with $2 \%$ sun flower oil supplementation having significantly $(\mathrm{p}<0.05)$ higher value compared to other treatments. The other reproductive characteristics of parents and growth and carcass characters of progeny re- mained unaltered due to different dietary sources of omega-3 and omega- 6 fatty acids.

\section{CONFLICT OF INTEREST}

We certify that there is no conflict of interest with any financial organization regarding the material discussed in the manuscript.

\section{ACKNOWLEDGMENTS}

This study was supported by TÜBITAK (No: 114O749) and BAP (No: ZF2013D12) of Çukurova University of Turkey.

\section{REFERENCES}

1. Cherian G, Sim, JS. Egg yolk polyunsaturated fatty acids and vitamin $\mathrm{E}$ content alters the tocopherol status of hatched chicks. Poult Sci 1997;76:1753-9. https://doi.org/10.1093/ps/ 76.12 .1753

2. Saber SN, Kutlu HR. Effect of omega-3 and omega- 6 fatty acid inclusion in broiler breeder's diet on laying performance, egg quality, and yolk fatty acids composition. Indian J Anim Sci 2018;88:1374-8.

3. Koppenol A, Buyse J, Everaert N, et al. Transition of maternal dietary n-3 fatty acids from the yolk to the liver of broiler breeder progeny via the residual yolk sac. Poult Sci 2015;94: 43-52. https://doi.org/10.3382/ps/peu006

4. Koppenol A, Delezie E, Wang Y, et al. Effects of maternal dietary EPA and DHA supplementation and breeder age on embryonic and post-hatch performance of broiler offspring. J Anim Physiol Anim Nutr 2015;99(Suppl S1):36-47. https:// doi.org/10.1111/jpn.12308

5. Khatibjoo A, Kermanshahi H, Golian A, Zaghari M. The effect of n-6/n-3 fatty acid ratios on broiler breeder performance, hatchability, fatty acid profile and reproduction. J Anim Physiol Anim Nutr 2018;102:986-98. https:/doi.org/10.1111/ jpn.12904

6. Cherian G, Sim JS. Effect of feeding full fat flax and canola seeds to laying hens on the fatty acid composition of eggs, embryos, and newly hatched chicks. Poult Sci 1991;70:91722. https://doi.org/10.3382/ps.0700917

7. Attia YA, Burke WH, Yamani KA, Jensen LS. Daily energy allotments and performance of broiler breeders.: 2 . Females. Poult Sci 1995;74:261-70. https://doi.org/10.3382/ps.0740261

8. Ajuyah AO, Wang Y, Cherian G, Sunwoo H, Sim JS. The effect of maternal dietary omega 3 fatty acids on hatchability and growth of broiler chickens. Proc Aust Poult Sci Symp 2003;15:154-8.

9. An SY, Guo YM, Ma SD, Yuan JM, Liu GZ. Effects of different oil sources and vitamin $\mathrm{E}$ in breeder diet on egg quality, hatchability and development of the neonatal offspring. Asian- 
Australas J Anim Sci 2010;23:234-9. https://doi.org/10.5713/ ajas.2010.90140

10. Bozkurt M, Çabuk M, Alçiçek A. Effect of dietary fat type on broiler breeder performance and hatching egg characteristics. J Appl Poult Res 2008;17:47-53. https://doi.org/10.3382/japr. 2007-00008

11. Kidd MT. A treatise on chicken dam nutrition that impacts on progeny. Word's Poult Sci 2003;59:475-94. https://doi. org/10.1079/WPS20030030

12. Yang X, Guo Y. Modulation of intestinal mucosal immunity by dietary polyunsaturated fatty acids in chickens. Food Agric Immunol 2006;17:129-37. https://doi.org/10.1080/09540100 600918169

13. Puthpongsiriporn U, Scheideler SE. Effects of dietary ratio of linoleic to linolenic acid on performance, antibody production, and in vitro lymphocyte proliferation in two strains of leghorn pullet chicks. Poult Sci 2005;84:846-57. https:/doi.org/10.1093/ $\mathrm{ps} / 84.6 .846$

14. Fritsche KL, Cassity NA, Huang SC. Effect of dietary fat source on antibody production and lymphocyte proliferation in chickens. Poult Sci 1991;70:611-7. https://doi.org/10.3382/ ps.0700611

15. Ross (Aviagen). Parentstock Performance Objectives, Ross 308 FF-2016. Huntsville, AL, USA: Available from: www.aviagen. com (http://en.aviagen.com/assets/Tech_Center/Ross_PS// Ross308FF-PS-PO-EN-2016.pdf

16. McQuoid D. Operation of multiple-stage and single-stage incubation systems. World Poult 2000;18:18-22.

17. Ross (Aviagen). Broiler 308 Nutrition, Specifications, 2014. Huntsville, AL, USA: Available from:www.aviagen.com (http:// tmea.staging.aviagen.com/assets/Tech_Center/Ross_Broiler/ Ross-308-Broiler-Nutrition-Specs-2014r17-EN.pdf

18.Sahin EH, Sengor E, Yardimci M, Cetingul S. Relationship between pre-incubation egg parameters from old breeder hens, egg hatchability and chick weight. J Anim Vet Adv 2009; 8:115-9.

19.SAS Institue; SAS user's guide. Statistics. Version 5th Edition. Cary, NC, USA: SAS Institue Inc.; 2005.

20. Al-daraji HJ, Razuki WM, Al-hayani WK, Al-hassani AS. Effect of dietary linseed on egg quality of laying quail. Int J Poult Sci 2010;9:584-90. https://doi.org/10.3923/ijps.2010.584.590

21.Pirsaraei Z, Saki AA, Kazemi Ferd M, Saleh H. Effect of dietary tallow level on broiler breeder performance and hatching egg characteristics. J Anim Vet Adv 2011;10:1287-91. https://doi. org/10.3923/javaa.2011.1287.1291

22. Caston LJ, Squires ES, Leeson S. Hen performance, egg quality and sensory evaluation of eggs from SCWL hens fed dietary flax. Can J Anim Sci 1994;74:347-53. https://doi.org/10.4141/ cjas94-047

23. Freeman BM, Vince MA. Development of the avian embryo. New York, USA: John Wiley and Sons; 1974.

24.Speake BK, Murray AMB, Noble RC. Transport and transformations of yolk lipids during development of the avian embryo. Prog Lip Res 1998;37:1-32.

25. Wilson HR. Interrelationships of egg size, chick size, posthatching growth and hatchability. Word's Poult Sci 1991;47:5-20. https://doi.org/10.1079/WPS19910002

26. Pappas AC, Acamovic T, Sparks NHC, Surai PF, McDevitt RM. Effects of supplementing broiler breeder diets with organoselenium compounds and polyunsaturated fatty acids on hatchability. Poult Sci 2006;85:1584-93. https://doi.org/10.1093/ ps/85.9.1584

27. Kidd MT, McDaniel CD, Peebles ED, et al. Breeder hen dietary L-carnitine affects progeny carcass traits. Br Poult Sci 2005; 46:97-103. https://doi.org/10.1080/00071660400024027 